研 究 報 文

熱分解ガスクロマトグラフィーによる

リグニンの構造解析 (第 7 報 $)^{* 1}$

木材パルプの酸加水分解条件と酸不溶性残さの性状*2

筑波大学農林工学系 大井 洋, 具延, 黒田健一

\title{
Structural Analysis of Lignin by Pyrolysis-Gas Chromatography (VII) \\ Conditions for Acid Hydrolysis of Wood Pulps and Characteristics of Acid-Insoluble Residues
}

Hiroshi Ohi, Yan Ju and Ken-ichi Kuroda

Institute of Agricultural and Forest Engineering, The

University of Tsukuba

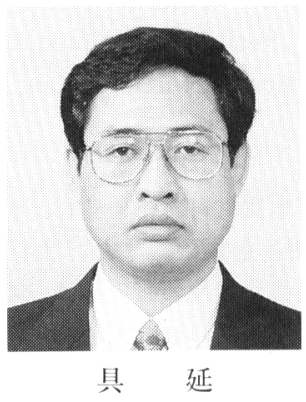

Acid-insoluble lignin can be hardly analyzed by spectroscopy because of the insoluble character in all organic solvents, and hence its chemical characteristics are not sufficiently clarified. To know the lignin content and the carbohydrate composition in pulps and woods, standard methods: JIS, Japan TAPPI, and TAPPI methods have been used, but different conditions for acid hydrolysis are chosen in these methods. It is required that conditions for acid hydrolysis are modified to shorten the time for determining the lignin content and the carbohydrate composition in many samples. To characterize the acid-insoluble residues prepared under various acid-hydrolysis conditions, pyrolysis-gaschromatography (Py-GC) is expected to be effective. In this paper, chemical characteristics of acid-insoluble lignins were discussed using $\mathrm{Py}-\mathrm{GC}$ in order to find an improved method for determining the lignin content and the carbohydrate composition.

The treatment period of the primary acid hydrolysis with $72 \%$ sulfuric acid should be at least 2.5 hours for analyzing lignin and carbohydrate composition in pulps and wood meals. If it is less than 1 hour, acid hydrolysis of cellulose is not sufficient, and in this case, it is indicated by the pyrogram of the acid-insoluble residue that there are some

*1 紙パ技協誌，51（8），1213１223（1997）を第6 報とする（大井，黑田 2 氏は第 2 報：紙パ技協誌，48， 1212 にて紹介)。

*2 本報の一部は, 第 46 回日本木材学会大会（1996 年 4 月，熊本）において発表した。 
peaks originating from holocellulose. This pyrogram also shows that the guaiacol peak is higher than the 4-methylguaiacol peak and is quite different from that of the acid insoluble lignin given by the Klason lignin method (the JIS method). Therefore, the J. TAPPI and TAPPI methods for determining the carbohydrate composition should be modified in their periods, which should be at least 2.5 hours. The modified method for carbohydrate composition, the Klason lignin method (the JIS method), and the modified Klason lignin method by Yoshihara give similar results on lignin contents and on pyrograms of the lignin residues in the case of akamatsu (Pinus densiflora) wood meals. In the case of akamatsu pulps, the yield of acid insoluble residue by the modified method for carbohydrate composition is slightly lower than the lignin content by the Klason lignin method (the JIS method), but the two methods show similar pyrograms of the lignin residues. It is concluded by the $\mathrm{Py}^{-}$ GC results that the modified method for carbohydrate composition can be used for determining the lignin content in many wood and pulp samples.

Keywords: pyrolysis, gas chromatography, acid-insoluble lignin, carbohydrate, acid hydrolysis

\section{1. 緒言}

木材とパルプに含まれるリグニンの定量法として， $72 \%$ 硫酸を用いて炭水化物を加水分解し，リグニンを 残さとして尘量するうj法（Klason 法）が古くから採 用されている。このう法は他の方法より操作が簡単で あり, 日本, 米|目, スウェーデンなどの紙パルプ試騃 法において標準法となっている。各国の定量法は細部 の点で買なるが, 基本的には試料に濃硫酸（72\%）を 加え， $20^{\circ} \mathrm{C}$ で一定時間（例えば 4 時間）放置したのち, 水を加之て希硫酸（3\%）にして沸騰処理する。放冷 してからがラスフィルターで吸引ろ過し，科量する。 一」，リグニンの一部は加水分解に用いた酸に溶解す る。この酸叮溶性リグニンは紫外線スペクトル法によ り，205〜210 nm または $280 \mathrm{~nm}$ 付近の最大吸収波長 の吸光度を测定して䦌接的に等量される。ここで注意 すべきことは，リグニン残さ（クラーソンリグニン） の收摔抢よび性状は, 使用する硫酸の濃度, 処理時間, および温渓によって影響されることである。濃度が $65 \%$ 以卜の硫酸を用いる場合, 通常の処理時間では多 糖の加水分解が不卜分であり， $80 \%$ 以上では多糖がフ ミン化により部分的に不溶物質となる危険がある。処 理時間の不足, あまりに低い温度での処理でも, 多糖 の加水分解は不十分となるが, 一方, 長い処理時間や 高温での処理でも，多糖由来の物質がリグニンと結合 し，異常に高いリグニン量を与えることになる1。

現在使われている酸不溶性りグニン定量法では, TAPPI 法と JIS 法で 72\%硫酸による処理（一次加水 分解）時間が異なっている。TAPPI 法では一次加水
分解は 2 時間, JIS 法では 4 時間である。なお, 希釈 後の $3 \%$ 硫酸による処理（二次加水分解）は共に 4 時 間である。一方, 吉原らは加水分解の条件について詳 細に検討し， $72 \%$ 硫酸による一次加水分解は 2 24 時 間, $10 \sim 25^{\circ} \mathrm{C}$ の範囲で分析值に差がなく, 簡便法とし ては, 3 時間, $20^{\circ} \mathrm{C}$ の一次加水分解, 硫酸濃度 $3 \%$, $121^{\circ} \mathrm{C}, 30$ 分の二次加水分解が適当であることを示し な2)。しかし, 処理条件の違いが酸不溶性残さの性状 へ及ぼす影響は明らかにされていない。

また，木材パルプの構成糖分析では一次加水分解の 処理を 1 時間とする場合が多い ${ }^{3,4)}$ 。ただし, 二次加 水分解は, 硫酸濃度 $4 \%$, 温度 $121^{\circ} \mathrm{C}$, 加温時間 1 時 間で処理される。この一次加水分解の条件については, リグニン定量法と構成糖分析法に相違がある。吉原ら の結果に基づくと 1 時間の処理では酸不溶性残さ収率 が大きくなり，多糖の加水分解が不十分であると考之 られる。このことから, 加水分解の条件をもつと詳細 に検討する必要がある。

酸不溶性リグニンは全ての有機溶媒に不溶であり， 分光法によって分析することが難しいため，その化学 的特徴が十分に明らかにされていない。種々の条件で 調製された酸不溶性残さの性状を明らかにするために, 熱分解ガスクロマトグラフィー $(\mathrm{Py}-\mathrm{GC})$ は有効な 方法であると期待される。

そこで本研究では，木材およびパルプに含まれるリ グニンと構成糖を簡便に分析するために, その加水分 解条件を改良することを試みた。さらに改良法の諸条 件を検討するために, Py-GC を用いて酸不溶性残さ の性状について調べた。 


\section{2. 実験}

\section{1 供試材料}

アカマツ (Pinus densiflora) 材脱脂木粉（40６0 メッシュ), アカマッホロセルロース (収率 69.7\%), およびアカマッ材チップより調製したパルプ (パルプ の蒸解条件，カッパー価等の蒸解結果を表 1 に示す) を用いた。ホルセルロースの調製では，脱脂木粉を 1 $\mathrm{g}$ 精科して $100 \mathrm{~m} l$ 容耐圧瓶にいれ, 蒸留水 $60 \mathrm{~m} l$ を 加えてから悪塩素酸ナトリウム $0.5 \mathrm{~g}$ および氷酢酸 $0.1 \mathrm{~m} l$ を加え, $70 \sim 80^{\circ} \mathrm{C}$ の湯浴中で時々振りながら 1 時間加熱した。この操作を 5 回行ってから濾別し, アセトンで洗って乾燥した。

\section{2 加水分解と酸不溶性残さの定量}

酸加水分解は以下の 4 つの方法で行った。

(1) クラーソンリグニン法 (JIS 法)

約 $1 \mathrm{~g}$ の試料を精科して $50 \mathrm{~m} l$ ビーカーに入れ, $72 \%$ 硫酸を $15 \mathrm{~m} l$ 加え， $20^{\circ} \mathrm{C}$ でガラス棒で時々攪は んしながら 4 時間の処理を行った (一次加水分解)。 次に試料の硫酸濃度を $3 \%$ に希䣋し， $100^{\circ} \mathrm{C}$ で時々水 を補充しながら 4 時間惹沸した (二次加水分解)。

その後, 一昼夜放置冷却し, JIS 規格の $1 \mathrm{G} 3$ (柴 田製 1G 4）ガラスフィルターで残さをろ別して洗浄, 乾燥し, 酸不溶性残さの収率を測定した。

(2) 吉 原 法

約 $1 \mathrm{~g}$ の試料を精科して $50 \mathrm{~m} l$ ビーカーに入れ，
$72 \%$ 硫酸を $15 \mathrm{~m} l$ 加え， $20^{\circ} \mathrm{C}$ でガラス棒で時々攪は んしながら 2.5 時間の処理を行った (一次加水分解)。 次に試料の硫酸濃度を $3 \%$ に希釈し，平山製作所製才 ートクレーブ (SV-302 AUTOCLAVE) 内に置き, $121^{\circ} \mathrm{C}$ で 30 分間，加水分解を行った（二次加水分解）。 なお, $100^{\circ} \mathrm{C}$ から $121^{\circ} \mathrm{C}$ に達するまでには 9 分間を要し, $121^{\circ} \mathrm{C}$ から $100^{\circ} \mathrm{C}$ まで降温するまでに 13 分間を要した。

(3) 構成糖分析法

約 $0.3 \mathrm{~g}$ の試料を精科して $20 \mathrm{~m} l$ ビーカーに入れ, $72 \%$ 硫酸を $3 \mathrm{ml}$ 加え， $30^{\circ} \mathrm{C}$ でガラス棒で時々攪はん しながら 1 時間の処理を行った (一次加水分解)。次 に試料を $4 \%$ に希橎し，平山製作所製オートクレーブ (SV-302 AUTOCLAVE) 内に置き， $120^{\circ} \mathrm{C} て ゙ 1$ 時間， 加水分解を行った (二次加水分解)。开温および降温 速度は(2)とほぼ同等であった。

(4) 構成糖分析改良法

構成糖分析法の一次加水分解の処理時間を 2.5 時間 に改良し，その他は(3)と同じ方法で行った。

\section{3 熱分解ガスクロマトグラフィー}

酸不溶性残さは前報の方法占に従って $\mathrm{Py}-\mathrm{GC} に よ$ り分析し，加水分解条件によるパイログラムの違いに ついて比較を行った。また，比較としてホロセルロー スの分析を行った。

熱分解装置：日本分析工業製 JHP-3 型，ガスクロ マトグラフ：島津製作所製 $\mathrm{GC}-14 \mathrm{~A}$ ，熱分解温度： $500^{\circ} \mathrm{C}$, 熱分解時間 : 4 秒,パイロライザー温度 : $270^{\circ} \mathrm{C}$,

Table 1 Pulping of akamatsu (Pinus densiflora) wood chips by different methods

\begin{tabular}{l|c|c|c|c}
\hline \multicolumn{1}{c|}{ Sample no. } & $\begin{array}{c}\mathrm{SFQ}^{\mathrm{a})} \\
\text { No.11 }\end{array}$ & $\begin{array}{c}\text { Kraft } \\
\text { No.22 }\end{array}$ & $\begin{array}{c}\text { Kraft-AQ } \\
\text { No.24 }\end{array}$ & $\begin{array}{c}\text { PS-AQ } \\
\text { No.25 }\end{array}$ \\
\hline Pulping liquor & b) & c) & c) & c) \\
Liquor ratio, L/kg & 6 & 5 & 5 & 5 \\
Time at 170 C, min. & 120 & 90 & 90 & 90 \\
Additive, & $\mathrm{SAQ}^{\mathrm{d})}$ & & $\mathrm{DAQ}^{\mathrm{e})}$ & $\mathrm{SAQ}$ \\
dosage, \% & 0.5 & 0 & 0.1 & 0.1 \\
sulfur, \% & 0 & 0 & 0 & 1 \\
Screened yield, \% & 54.5 & 43.4 & 44.2 & 45.2 \\
Rejects, \% & 14.3 & 2.8 & 2.0 & 1.4 \\
Kappa no. & 49.5 & 36.0 & 30.3 & 26.8 \\
\hline
\end{tabular}

Notes : a) : Sulfite-Formaldehyde-Quinone Pulping [Ohi, H. et al., JAPAN TAPPI J., 41(8), 708-716 (1987)]

b) $: 0.9 \mathrm{~mol} / \mathrm{L} \mathrm{Na} \mathrm{SO}_{3}, 0.2 \mathrm{~mol} / \mathrm{L} \mathrm{HCHO}$

c) : active alkali $19 \%$, sulfidity $25 \%$

d) : 1,4-dihydro-9,10-dihydroxyanthracene sodium salts

e) : anthraquinone (emulsion type) 
トランスファーチューブ温度 : $270^{\circ} \mathrm{C}$, 試料注入法： 直接導入法, インジェクション温度 : $170^{\circ} \mathrm{C}$, カラ 厶 : Ultra-ALLOY - $(8 \mathrm{H})-1(0.8 \mathrm{~mm} \phi \times 30 \mathrm{~m}$, 膜 厚 $2 \mu \mathrm{m})$, カラム温度: $50^{\circ} \mathrm{C}$ で 1 分間保持後, $5^{\circ} \mathrm{C} /$ $\min$ で $270^{\circ} \mathrm{C}$ まで昇温, $270^{\circ} \mathrm{C}$ で保持, 検出器: FID, 検出器感度: $10^{1}$, 検出器温度 $: 270^{\circ} \mathrm{C}$ 。

\section{4 構成糖の分析}

一次㧍よび二次加水分解を行った試料について，ア ルジトールアセテート法 ${ }^{6)}$ に準じて以下の手順で行っ な。

（1）内部標準としてイノシトールを添加し，残さと 溶液を濾別し, 水酸化バリウムによって溶液を中和し た。

（2）遠心分離によって硫酸バリウムを除去し，上澄 み液を採取した。

（3）水素化ホウ素ナトリウムによって溶液中の単糖 を還元した。

(4) 酢酸を添加して溶液を濃縮した。さらにメ夕ノ 一ルを添加して濃縮, 乾固を 2 回繰り返した。

(5) 試料を $105^{\circ} \mathrm{C}$ で乾燥し, 無水酢酸を添加して $120^{\circ} \mathrm{C}, 3$ 時間の処理によって試料をアセチル化した。

（6）濃縮した試料について，キャピラリーカラムに よるガスクロマトグラフィーでアラビノース，キシロ 一ス, マンノース, ガラクトース, グルコースのアル ジトールアセテートを定量した。

ガスクロマトグラフ：島津製作所製 GC-14 B，カ

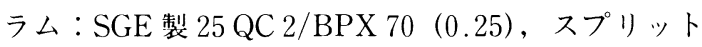
比: 1/50, キャリアーガス:ヘリウム $(110 \mathrm{kPa})$,
インジェクション温度 : $240^{\circ} \mathrm{C}$, カラム温度 : $210^{\circ} \mathrm{C}$, 検出器: $\mathrm{FID}$, 検出器温度: $280^{\circ} \mathrm{C}$, メイクアップ窒 素压：50 kPa。

\section{3. 結果と考察}

\section{1 各加水分解条件と酸不溶性残さ収率の違い}

アカマッ木粉についてクラーソンリグニン法（JIS 法）等の 4 つの方法によって定量した酸不溶性残さ収 率を表 2 に示す。構成糖分析法は他の 3 つの方法より 值が約 $8 \%$ 大きく, 構成糖分析改良法, 吉原法, およ び JIS 法はほぼ同等であった。これらは吉原らの結果 と一致する。

さらにアカマッパルプについてはいずれも構成糖分 析法による值が大きかった。また構成糖分析改良法は JIS 法よりも值がやや小さかった。

構成糖分析法（一次加水分解処理：1 時間） と構成 糖分析改良法 (一次加水分解処理 : 2.5 時間) の比較 から, 一次加水分解の処理時間は酸不溶性残さの収率 に大きな影響を与えることがわかった。なお，二次加 水分解の処理時間がどう影響するかについても検討し た。吉原法に基づいて, 一次加水分解を 2.5 時間, 二 次加水分解（硫酸濃度 $3 \%$ ）を $15 ， 30,60$ 分間とし て処理を行ったところ, 酸不溶性残さ収率はほぼ同じ 值が得られた。

\section{2 酸不溶性残さのパイログラムの違い}

酸不溶性残さの構造的特徵を把握するため, 残さを Py-GCで分析した。図 $1 \mathbf{A}$ はアカマツ木粉の構成糖 分析法 (一次加水分解処理：1 時間) による残さのパ

Table 2 Yields of acid-insoluble residues by four methods

\begin{tabular}{|c|c|c|c|c|c|c|}
\hline No. Names of methods & $\begin{array}{cr}\text { Conditions of hydrolysis } \\
\text { Primary } & \text { Secondary }\end{array}$ & $\begin{array}{l}\text { Yields of } \\
\text { akamatsu } \\
\text { wood }\end{array}$ & $\begin{array}{l}\text { acid-in } \\
\text { No.11 }\end{array}$ & $\begin{array}{l}\text { soluble } \\
\text { No. } 22\end{array}$ & $\begin{array}{l}\text { residues } \\
\text { No. } 24\end{array}$ & $\begin{array}{l}(\%) \\
\text { No. } 25\end{array}$ \\
\hline 1. Klason (JIS) & $\begin{array}{ll}72 \% \mathrm{H}_{2} \mathrm{SO}_{4}, & 3 \% \mathrm{H}_{2} \mathrm{SO}_{4}, \\
20^{\circ} \mathrm{C}, 4 \mathrm{~h} . & 100^{\circ} \mathrm{C}, 4 \mathrm{~h} .\end{array}$ & 28.3 & 4.3 & 4.6 & 3.4 & 3.8 \\
\hline $\begin{array}{l}\text { 2. Modified Klason by Yoshihara } \\
\text { (JAPAN TAPPI J., 38(4), } 466 \\
(1984)\end{array}$ & $\begin{array}{l}72 \% \mathrm{H}_{2} \mathrm{SO}_{4}, 3 \% \mathrm{H}_{2} \mathrm{SO}_{4} \\
20^{\circ} \mathrm{C}, 2.5 \mathrm{~h} . \quad 121^{\circ} \mathrm{C}, 30 \mathrm{~min} .\end{array}$ & 28.2 & - & - & - & - \\
\hline $\begin{array}{l}\text { 3. Carbohydrate composition } \\
\text { (J. TAPPI No. } 42^{-84} \text {, TAPPI } \\
\text { T } 249 \mathrm{~cm}-85)\end{array}$ & 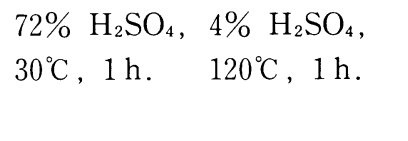 & 36.3 & 5.5 & 5.9 & 4.5 & 4.6 \\
\hline $\begin{array}{l}\text { 4. Modified carbohydrate compo- } \\
\text { sition }\end{array}$ & $\begin{array}{l}72 \% \mathrm{H}_{2} \mathrm{SO}_{4}, 4 \% \mathrm{H}_{2} \mathrm{SO}_{4} \\
30^{\circ} \mathrm{C}, 2.5 \mathrm{~h} .120^{\circ} \mathrm{C}, 1 \mathrm{~h} .\end{array}$ & 28.0 & 4.2 & 3.9 & 3.1 & 3.7 \\
\hline
\end{tabular}

Legend: No.11, No.22, No.24, and No.25 are shown in Table 1. 


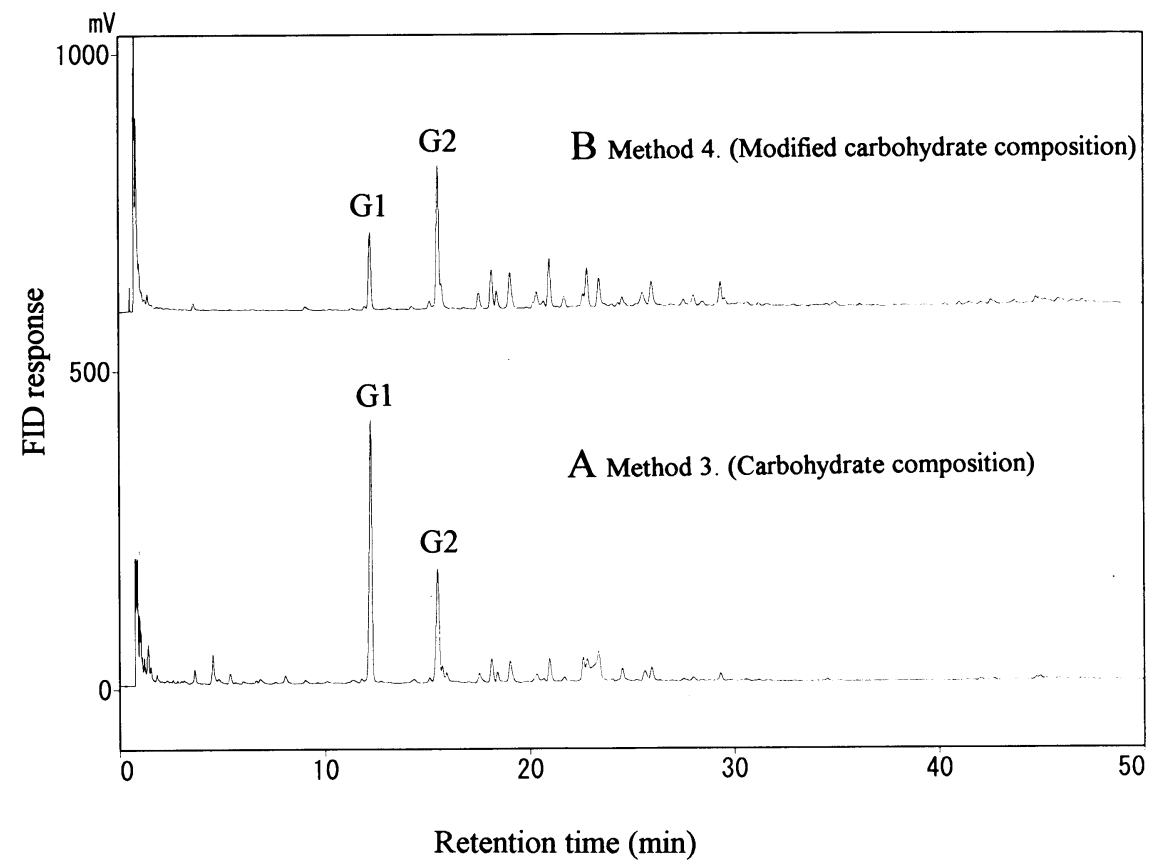

Fig. 1 Py-GC traces of acid-insoluble residues from akamatsu wood.

Legend: Method 3. and Method 4. are shown in Table 2.

G 1: guaiacol, G 2:4-methylguaiacol

イログラムである。また図 $1 \mathrm{~B}$ は構成糖分析改良法 (一次加水分解処理 : 2.5 時間)のパイログラムである。 一次加水分解処理が 1 時間のパイログラムでは, グア イアコールのほうが4-メチルグアイアコールよりピ 一クが高くなった。一方, 一次加水分解処理が 2.5 時 間のものではこれとは逆に，4-メチルグアイアコール がグアイアコールより高かった。なお, 図1Bのパイ ログラムは Kuroda ら゙がすでに報告したスギのクラ ーソンリグニンのパイログラムとほとんど同じである。 さらにアカマツ木粉を用いて一次加水分解だけ行っ た試料を調製した。一次加水分解処理を 1 時間および 2.5 時間とし，二次加水分解を行わずに残さをろ別し， その収率を求めたところ，それぞれ約 $47 \%$ と $28.9 \%$ であった。なお，前者の約 $47 \%$ という值については, 繰り返し試験によるバラツキが大きかった。これらの 残さのパイログラムを図 2 に示す。一次加水分解が 1 時間処理のパイログラム (A) では，グアイアコール のピークが4-メチルグアイアコールのピークよりも 高くなったが, 2.5 時間処理（B）では，4-メチルグ アイアコールのピークのほうがやや高かった。

前述のように, 二次加水分解処理の前後ではほぼ同 等の酸不溶性残さ収率（28.9\%および $28.0 \%$ ）を与
えた。また, 必 $1 \mathrm{~B}$ と四 $2 \mathrm{~B}$ の比較から, 2.5 時間の 一次加水分解処理の終了時にすでにかなりの部分のリ グニンの反応が進み, 二次加水分解処理の前後ではリ グニンの構造変化が意外と小さいことが示唆された。

図 3 にアカマッ木粉のクラーソンリグニン法 (JIS 法）と吉原法による残さパイログラムを示す。これら と構成糖分析改良法のパイログラム（四 1 B ) を比較 すると，それらはほとんど同一であった。このことか ら, それらの酸不溶性残さの化学的特徵は同一である と考えられる。なお，構成糖分析改良法の二次加水分 解処理において, 硫酸溶液の濃度を $4 \%$ から $3 \%$ に変 更した条件（吉原法の二次加水分解処理時間を 1 時間 とした条件）でも分析を行った。その酸不溶性残さの パイログラムは墽 $1 \mathrm{~B}$ および冈 3 とほとんど同一であ つた。

図 $4 \mathrm{~A}$ と B には，クラフトパルプ（No.22）につ いてクラーソンリグニン法（JIS 法）と構成糖分析改 良法によって得られた酸不溶性残さのパイログラムを それぞれ示す。前述のように酸不溶性残さ収率は後者 の方がやや小さかったものの, 両者のパイログラムは ほとんど同一であった。

多くの木材およびパルプ試料の分析をする場合には, 


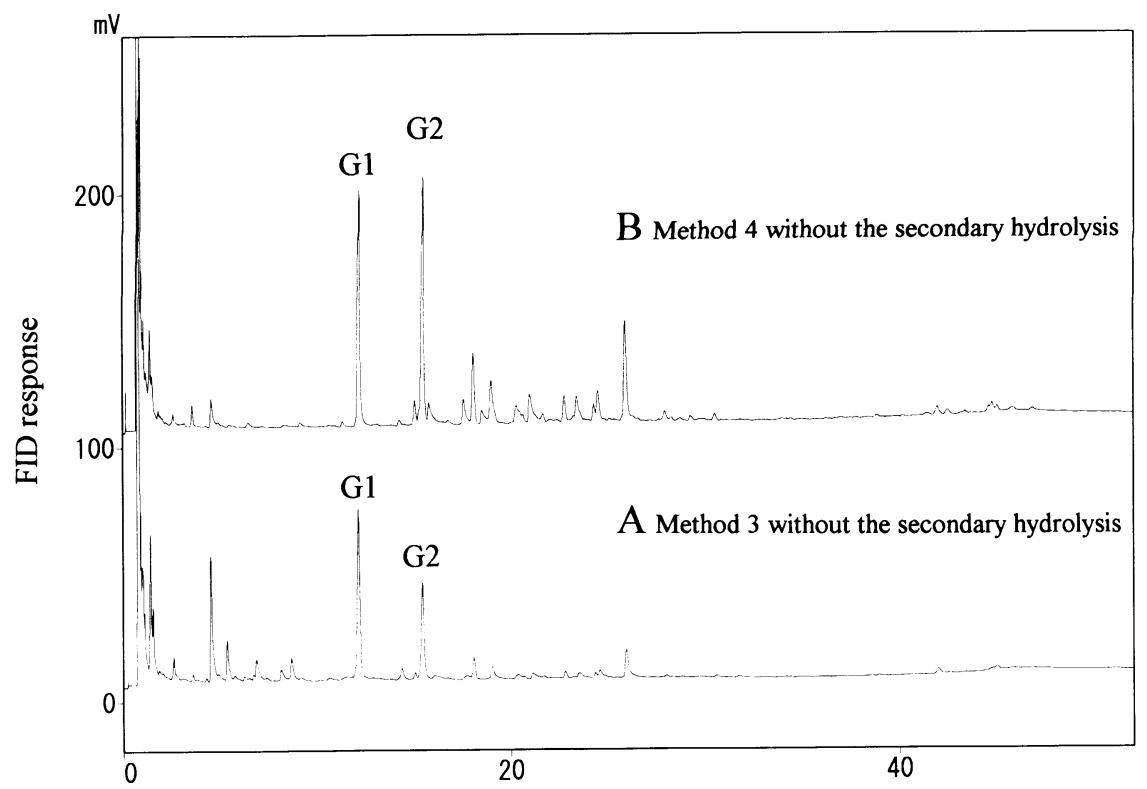

\section{Retention time ( $\mathrm{min})$}

Fig.2 Py-GC traces of residues (akamatsu wood) by the primary hydrolysis.

Legend : Method 3. and Method 4. are shown in Table 2.

G 1 : guaiacol, G $2: 4$-methylguaiacol

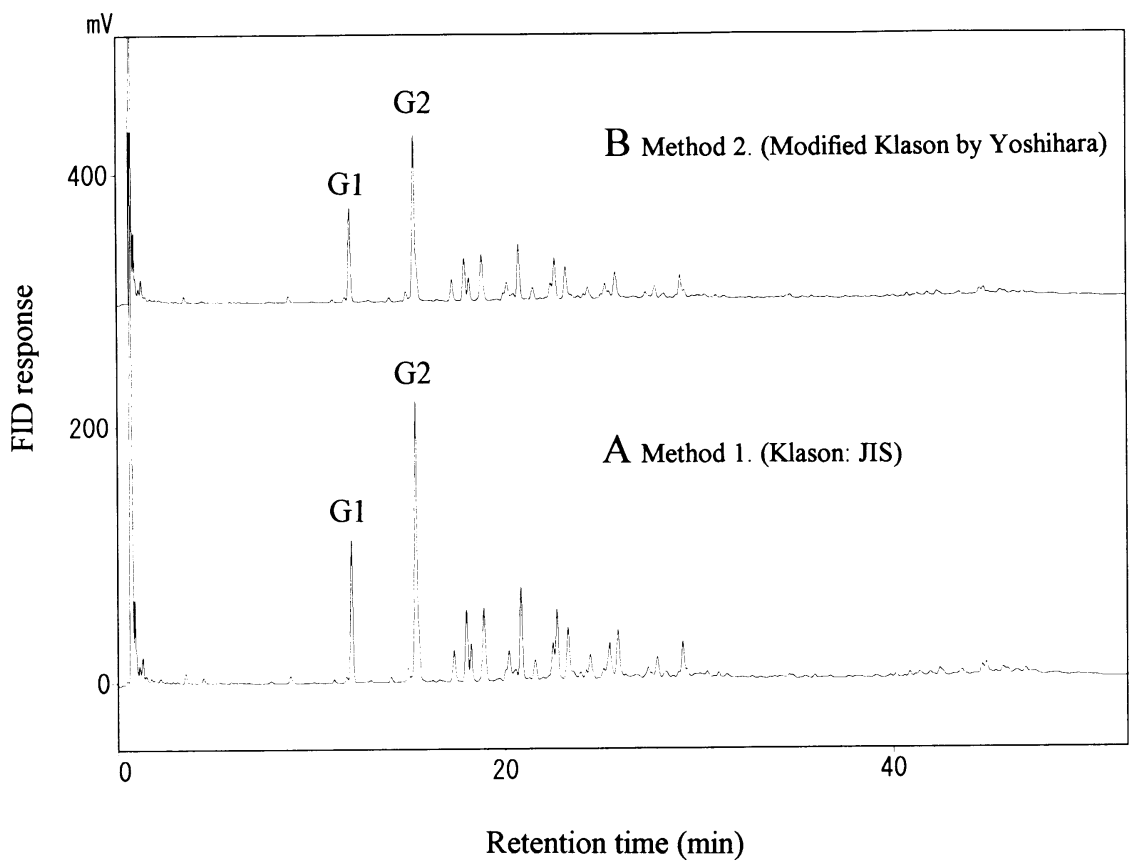

Fig.3 Py-GC traces of acid-insoluble residues from akamatsu wood by Klason and modified Klason methods.

Legend: Method 1. and Method 2. are shown in Table 2.

G 1 : guaiacol, G $2:$-methylguaiacol 


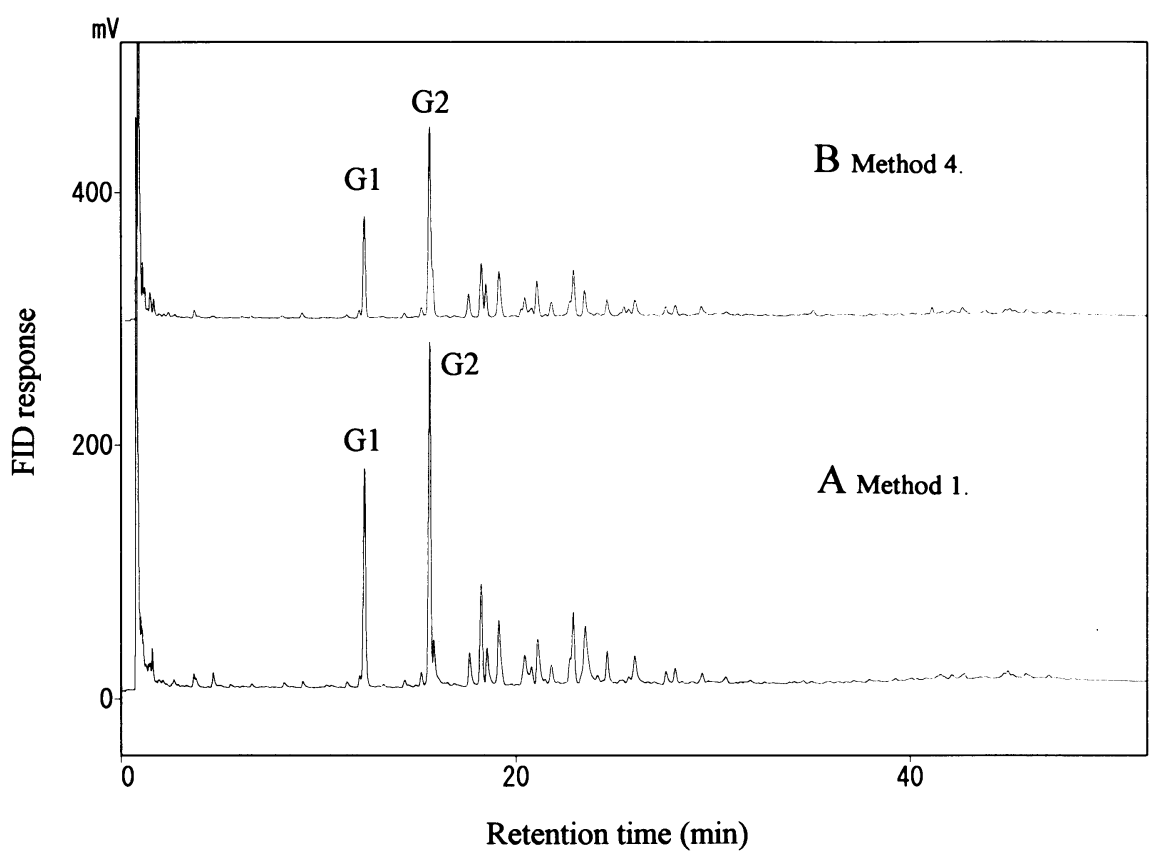

Fig.4 Py-GC traces of acid-insoluble residues from akamatsu pulp No. 22. Legend: Method 1. and Method 4. are shown in Table 2. G 1 : guaiacol, G $2: 4$-methylguaiacol

簡便法として構成糖分析改良法 $(2.5$ 時間の一次加水 分解, $120^{\circ} \mathrm{C}, 1$ 時間の二次加水分解）によって処理 を行い，その酸不溶性残さ収率をリグニン収率とし， 同時にろ液中の構成糖を分析することを提案する。

\section{3 酸不溶性残さとホロセルロースのパイロ グラムの比較}

前に述べたように，構成糖分析法では他の方法と比 べて酸不溶性残さ収率が高かった。そのため, 一次加 水分解 1 時間処理の残さには糖の成分が残っている可 能性がある。これを確認するため, 酸不溶性残さと木 ロセルロースをPy-GCで分析し，そのパイログラム を比較した（図 5)。酸不溶性残さのパイログラムの C印のピークは糖成分由来のピークである。

\section{4 加水分解条件と構成糖分析の值}

木材の構成糖分析法，およびJ. TAPPI 法では一 次加水分解の処理時間はいずれも 1 時間となっている。 この条件は炭水化物の加水分解が不十分であることが 示唆された。このことをさらに確かめるために，アカ マッ木粉の一次加水分解処理時間が構成糖収率へ及ほ す影響を調べた（図6）。アラビノース，キシロース， マンノース，ガラクトースのへミセルロース成分の収 率はほとんど同じ值になったが, グルコース収率は 1 時間処理の場合が $19.6 \% ， 2.5$ 時間が $41.0 \%$ となり，
その違いは大きかった。処理時間が短いと酸不溶性残 さ中にセルロースが残存することがわかった。したが って, J. TAPPIおよびTAPPIの構成糖分析法に ついてはこの処理を 2.5 時間に改良するべきである。

\section{5 加水分解条件と酸可溶性リグニン量}

各方法によるアカマツ木粉の酸可溶性リグニン量を 表 3 に示す。これらを比較すると, 酸可溶性りグニン 量は二次加水分解の温度が高いほど值が大きく，また， 一次加水分解の処理時間が長いほど, または二次加水 分解の硫酸濃度が大きいほど值は大きかった。しかし， 紫外部に吸収を持つ糖変質物が生成して分析值に影響 を与えたことも考えられ，さらに詳細な検討が必要で

Table 3 Observed yields of acid-soluble lignin (akamatsu wood)

No. Names of methods

Observed yield

(\%)

$\begin{array}{ll}\text { 1. Klason (JIS) } & 0.27 \\ \text { 2. Modified Klason by Yoshihara } & 0.83 \\ \text { 3. Carbohydrate composition } & 0.44 \\ \text { 4. Modified carbohydrate composition } & 1.09\end{array}$




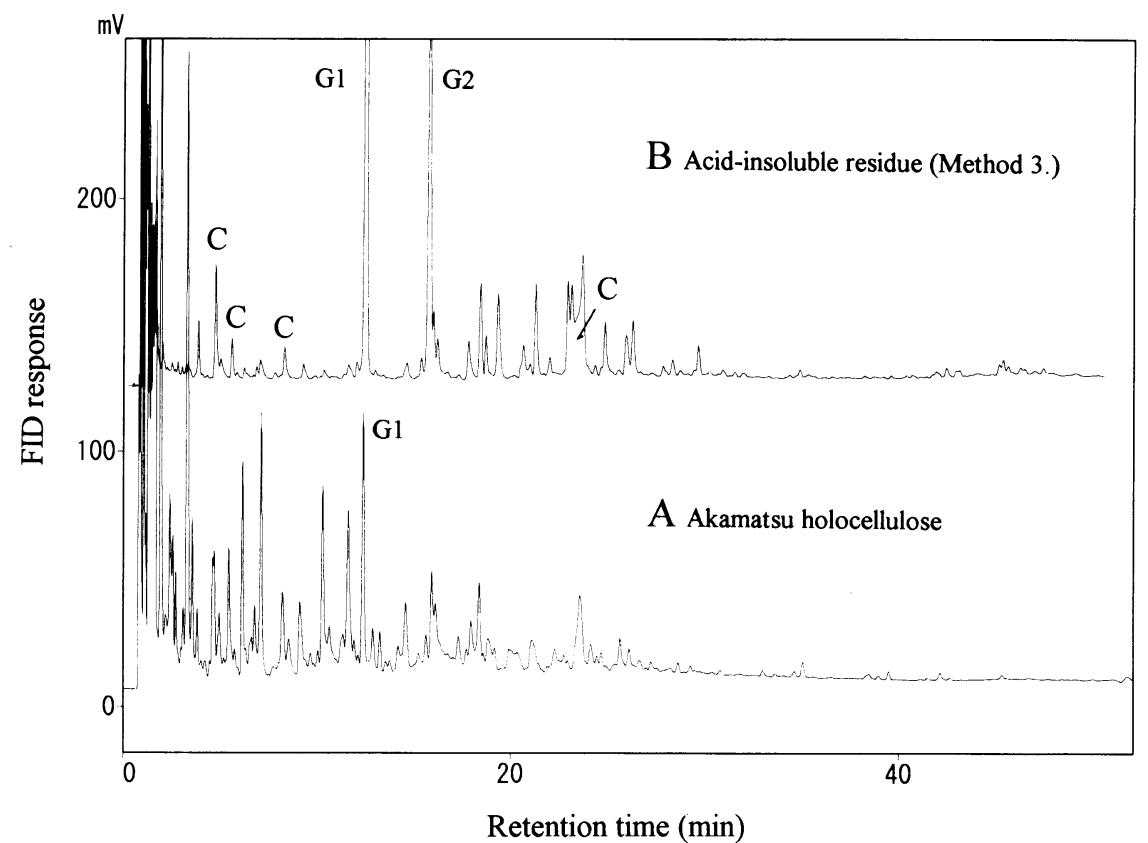

Fig.5 Py-GC traces of acid-insoluble residue and holocellulose from akamatsu wood.

Legend: Method 3. is shown in Table 2.

C: pyrolysis products from carbohydrates, G $1:$ guaiacol, G $2: 4^{-}$ methylguaiacol

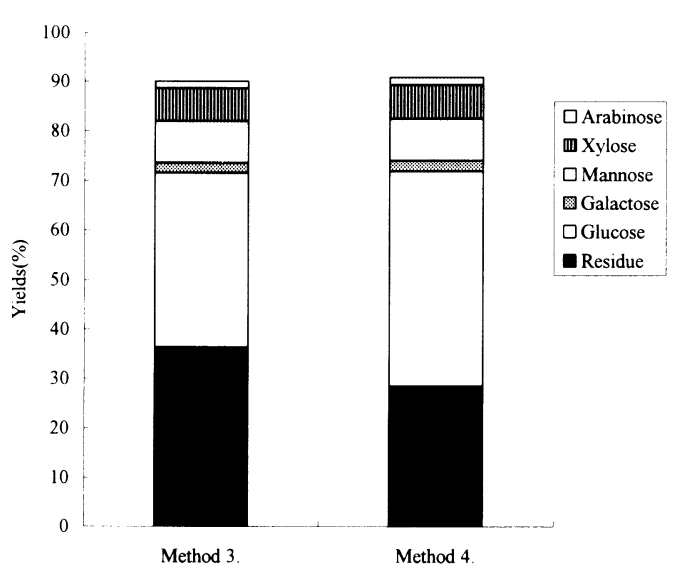

Fig. 6 Carbohydrate composition of akamatsu wood.

Legend : Method 3. and Method 4. are shown in Table 2.

ある。なお，パルプの分析においても同様の傾向が認 められた。

前述のようにパルプの分析の場合，二次加水分解を
$120 \sim 121^{\circ} \mathrm{C} ， 30$ 分 1 時間の条件で行うと, 酸不溶性 残さ収率がクラーソンリグニン法（JIS 法）よりも小 さくなる傾向が恋められた。また，一次加水分解処理 を 1 時間とすると酸不溶性残さ収率が大きくなった。 パルプ分析において構成糖分析法（1 時間の一次加水 分解, $120^{\circ} \mathrm{C}, 1$ 時間の二次加水分解）による処理を 行った場合, これらが相殺されて值が結果的に JIS 法 に近づくが，この方法によってリグニンと構成糖を分 析することは適当でない。

パルプの分析において，構成糖分析改良法による酸 不溶性残さ収率がクラーソンリグニン法（JIS 法）よ りも小さい理由は今のところ明確ではない。残さのパ イログラムがほとんど同一であることから考えて，比 較的高温の処理ではパルプに含まれる糖変質物あるい は残存リグニンの一部が可溶化することが理由の一つ として推定される。

\section{4. 結論}

(1) 木材およびパルプ中のリグニンと構成糖を分析 する場合， $72 \%$ 硫酸による一次加水分解処理では処理 時間を 2.5 時間とする必要がある。処理時間が 1 時間 
であると, セルロースの膨潤とその後の加水分解が不 十分である。J，TAPPI および TAPPI の構成糖分析 法についてはこの処理を 2.5 時間に改良するべきであ る。

（2）一次加水分解の処理時間が 1 時間であると, 酸 不溶性残さのパイログラムでは, グアイアコールのピ ークが4-メチルグアイアコールのピークより高い。

（3）アカマツ木粉の場合は，クラーソンリグニン法 (JIS 法), 吉原法, および構成糖分析改良法では二次 加水分解処理条件が違っても酸不溶性残さの収率とパ イログラムの特徴はほぼ同等であった。

(4) アカマツパルプの場合は, 構成糖分析改良法に よる酸不溶性残さ収率はクラーソンリグニン法（JIS 法）による値よりもやや小さかったが, 両者のパイロ グラムの特徵はほぼ同等であった。

(5) 酸不溶性残さのパイログラムがほとんど同一で あることから判断して，多くの木材およびパルプ試料 の分析をする場合には，構成糖分析改良法を用いてリ
グニン定量を行うことができる。

\section{引用文献}

1）中野準三, 飯塚克介（翻訳・監修）：リグニン化 学研究法, 工二出版, p.22-23 (1994).

2）吉原一年，小林武，藤井利郎，赤松勲：紙八技協 誌, 38 (4)，466-475 (1984).

3）J. TAPPI 紙パルプ試験方法No. $42^{-84}$ : 紙パ技 協誌，38（3），361-364（1984）。

4) TAPPI TEST METHODS T $249 \mathrm{~cm}-85$ : TAPPI TEST METHODS 1996-1997, TAPPI PRESS, (1996).

5）和泉明子, 黑田健一, 大井洋，山口彰：紙八゙技協 誌，49 (9)，1339-1346 (1995).

6) 篠田善彦, 稲葉政満：日本木材学会編增補改訂木 材科学実験書 II 。化学編, p.191-194 (1989).

7) Kuroda, K., Yamaguchi, A., Sakai, K. : Mokuzai Gakkaishi, 40 (9), 987-995 (1994). (受理：'97.4.22) 